\title{
Morphological study of epididymides in the scorpion mud turtle in natural habitat (Kinosternon scorpioides - Linnaeus, 1976)
}

\author{
Diego C. Viana ${ }^{1}$ \\ Leandro A. Rui ${ }^{1}$ \\ Maria A. Miglino ${ }^{1}$ \\ Lianne P. F. Araujo ${ }^{2}$ \\ Antonia S. Oliveira ${ }^{2}$ \\ Alana L. Sousa ${ }^{2 *}$ \\ ${ }^{1}$ Department of Surgery, School of Veterinary Medicine and Animal Science, University of Sao Paulo \\ Avenida Prof. Dr. Orlando Marques de Paiva, 87, CEP 05508-270, Sao Paulo - SP, Brazil. \\ ${ }^{2}$ Department of Clinical Veterinary, School of Veterinary Medicine and Animal Science \\ State University of Maranhao, Cidade Universitaria Paulo VI, CEP 65054-970, Sao Luis - MA, Brazil. \\ * Corresponding author \\ alana@elo.com.br
}

Submetido em 08/06/2012

Aceito para publicação em 14/01/2013

\section{Resumo}

Estudo morfológico dos epidídimos de jurará em habitat natural (Kinosternon scorpioides - Linnaeus, 1976). No estado do Maranhão, é encontrado o quelônio de água doce Kinosternon scorpioides, conhecido como jurará, que possui valor social, econômico e ambiental. Vinte jurarás adultos foram coletados nos meses de março, junho, setembro e dezembro, correspondendo aos dois períodos do ano: as estações chuvosa e seca. De cada animal colheram-se os epidídimos para averiguar a existência de sazonalidade reprodutiva. Os órgãos foram avaliados por microscopia de luz e eletrônica de varredura e de transmissão e analisados à altura do epitélio epididimário e os diâmetros tubular e luminal. Os epidídimos estavam divididos em rede testis, ducto eferente e ducto epididimário. Na estação chuvosa, eles apresentaram, epitélio pseudoestratificado estereociliado; na estação seca, eles se caracterizaram por células simples, cúbicas e não ciliadas. A morfometria dos diâmetros tubular e luminal e a altura epitelial do epidídimo apresentaram momentos de alternância epitelial ao longo dos períodos estudados, com as maiores médias na estação chuvosa, no período reprodutivo. Os espermatozoides foram observados durante o ano todo, apesar de sua viabilidade não poder ser avaliada. Tendo em vista os dados obtidos, pode-se afirmar que o jurará apresenta sazonalidade reprodutiva.

Palavras-chave: Fauna silvestre; Morfometria epididimária; Reprodução; Sazonalidade reprodutiva

\section{Abstract}

In the state of Maranhao, Brazil, one can find the freshwater chelonian Kinosternon scorpioides, known as scorpion mud turtle, which has social, economic, and environmental value. Twenty adult scorpion mud turtles were collected in the months of March, June, September, and December, corresponding to the two periods of the year: the rainy and dry seasons. The epididymides were collected from each animal to check the existence 
of reproductive seasonality. The organs were evaluated through light, scanning electron, and transmission microscopy and analyzed at the epididymal epithelium height and the tubular and luminal diameters. The epididymides were divided into rete testis, ductuli efferentes, and ductus epididymis. In the rainy season, they presented stereo ciliated pseudostratified epithelium; in the dry season, they were characterized by simple, cubic, and non-ciliated cells. The morphometry of the tubular and luminal diameters and the epididymal epithelium height showed moments of epithelial alternation over the studied periods, with the highest averages in the rainy season, within the reproductive period. Spermatozoids were observed throughout the year, although their viability couldn't be evaluated. Taking into account the data obtained, one may claim that the scorpion mud turtle presents reproductive seasonality.

Key words: Epididymal morphometry; Reproduction; Reproductive seasonality; Wild fauna

\section{Introduction}

Brazil has 35 chelonians species distributed in its various terrestrial and aquatic ecosystems, among which 28 species are freshwater, 2 are terrestrial, and 5 are marine turtles (SBH, 2005). The Kinosternidae family consists of small to medium sized semi-aquatic species, distributed from Canada to South America (ERNST; BARBOUR, 1989). It's made up of 22 species, subdivided into 4 genera: Kinosternon, Sternotherus, Staurotypus, and Claudius. In the Brazilian Amazon, one can find only 1 species in this family, Kinosternon scorpioides, popularly known as mucua in the state of Para and as scorpion mud turtle in the state of Maranhao (ROCHA; MOLINA, 1987).

The scorpion mud turtle is preferably an aquatic species and it inhabits both stagnant and flowing water, being also able to develop a semi-aquatic behavior (PRITCHARD; TREBBAU, 1984). It displays a shell with three apparent keels, especially the median keel, which goes through the shell in the longitudinal direction (VANZOLINI et al., 1980).

Kinosternon scorpioides is well distributed in the South America coast, including Colombia, the Guianas, and Trinidad. In Brazil, it's found in the states of Para, Maranhao, Goias, Ceara, Rio Grande do Norte, and Pernambuco (PRITCHARD; TREBBAU, 1984). In Maranhao, there're records of this species on the edge of rivers (PEREIRA, 2004).

The state of Maranhao is characterized as an area with special features according to the period of the year, i.e. rain and dry seasons, with the formation of flooded zones in the form of swamps from January to June, when fishing is the main subsistence activity. At the end of this period, in the beginning of summer, from July to December, these areas become dry and start being used for agricultural crops, also cultivated on a subsistence basis (PEREIRA et al., 2007), and both animal and agricultural species interact in this environment within their cycles.

The male reproductive system consists of a pair of oval testes with variable size, between light yellow to golden yellow color, and fixated by mesorchium and mesocolon: the epididymis is located along the dorsal part of the medial surface of each testis, it is very delicate and presents convoluted structures with whitish color; and the vas deferens, which is continuous to the epididymis, culminates in the cloaca region. The ductus deferens in the scorpion mud turtle consists of a pair of simple structures, with a convoluted path extending from the epididymis to the cloaca, and it has the function of transporting and storing spermatozoids. The penis, in turn, is grooved and consists of root, body, and gland, located in the ventral floor of the cloaca, where it's fixated by a retractor muscle, and protected by the foreskin (CARVALHO et al., 2010).

This study aimed to characterize the morphology of the epididymis in Kinosteron scorpioides through microscopic analysis in the dry and rainy seasons, in order to check its seasonality.

\section{Material and Methods}

Twenty adult male scorpion mud turtles were used, captured in situ at the town of Sao Bento, state of Maranhao, Brazil. The research was developed under the 
Authorization 26136-1 from the Chico Mendes Institute for Biodiversity Conservation (ICMBio) and approved by the Ethics and Animal Research Committee from the Veterinary Medicine Course of the State University of Maranhao (UEMA), under the Protocol 011/2010.

The study was carried out at the Laboratory of Veterinary Anatomy and Anatomopathology from the Center for Agricultural Sciences of State University of Maranhao (UEMA) in Sao Luis, Maranhao, Brazil, and at the laboratories of Light Microscopy and Electron Microscopy from the School of Veterinary Medicine and Animal Science of University of Sao Paulo (USP).

The animals were collected at regular intervals during the year and divided into four experimental groups in the rainy and dry seasons; the rainy season consists of collections conducted in March 2011 ( $\mathrm{n}=$ 5) and June $2011(\mathrm{n}=5)$ and the dry season consists of collections conducted in December $2010(\mathrm{n}=5)$ and September $2011(\mathrm{n}=5)$. Values regarding temperature, humidity, and rainfall were recorded within these periods.

All animals were anesthetized with $2 \%$ xylazine (40 $\mathrm{mg} / \mathrm{kg} / \mathrm{IM})$ and $1 \%$ ketamine hydrochloride $(60 \mathrm{mg} / \mathrm{kg} /$ IM), and they were euthanized by administration of $2.5 \%$ thiopental sodium $(60 \mathrm{mg} / \mathrm{kg} / \mathrm{EV})$ or catheterization of the cervical venous sinus, according to the technique described by Vanzolini et al. (1980) and Schumacher (1996). Subsequently, the opening of the coelomic cavity was performed using steel handsaw, in order to disarticulate the bone bridge connecting the carapace to the plastron; besides, there're visualization and removal of the reproductive tract and isolation of the epididymis. The process is specific to each microscopy.

For light microscopy, the epididymides were fixed in $4 \%$ buffered formaldehyde for about $24 \mathrm{~h}$ for paraffin embedding. Then, they were dehydrated in increasing alcohol concentrations (70\% to $100 \%)$ and diaphanized in xylol, with a $1 \mathrm{~h}$ switching interval between the solutions. After dehydration, the fragments were embedded in paraffin, sectioned at $4 \mu \mathrm{m}$ thickness, stained with hematoxylin-eosin (HE), Masson's trichrome, and periodic acid-Schiff(PAS), and examined under an optical microscope.
For scanning electron microscopy (SEM), the fragments were fixed in $2.5 \%$ glutaraldehyde, frozen for $72 \mathrm{~h}$, and, then, cryofractured in liquid nitrogen, washed in $0.1 \mathrm{M}$ phosphate buffer, post-fixed in $1 \%$ osmium tetroxide, and dehydrated in a series of alcohols $\left(50^{\circ}\right.$ to $\left.100^{\circ}\right)$. The samples were dried in a Balzers $\mathrm{CPD} 020$ critical point apparatus, using liquid $\mathrm{CO}_{2}$, and mounted on an aluminum basis (stub), using carbon paste. Subsequently, they underwent a metallic coating ("sputting") with gold in a EMITECH K550 sputter device, being analyzed and photographed under a LEO 435VP scanning electron microscope.

For transmission electron microscopy (TEM), the fragments were fixed in 2.5\% glutaraldehyde, washed in $0.1 \mathrm{M}$ phosphate buffer, and post-fixed in $1 \%$ osmium tetroxide. Subsequently, they were dehydrated in a series of increasing alcohols $\left(50^{\circ}\right.$ to $\left.100^{\circ}\right)$, propylene oxide, and resin. The resin mixture was replaced by pure resin and placed in molds. The ultrathin sections were collected on copper screens and contrasted with uranyl acetate solution at $2 \%$ and $0.5 \%$ lead citrate. The samples were analyzed in a MORGAGNI 268d transmission electron microscopy apparatus.

Images for morphometric studies were obtained using an Olympus BH-41 binocular microscope equipped with a digital camera for the photographic record. Histomorphometric analyses were performed with the aid of the GIMP 2 software to determine the average epididymal epithelium height and the luminal and tubular epididymal diameters, using a micrometric ocular adapted to the microscope. Ten slides were prepared with three serial sections, totaling thirty serial sections for each parameter; the tubular sections were around the tubules on the epithelial bottom, at the basal membrane level, to obtain the total tubular diameter, and that adjacent to the apical edge, in order to obtain the luminal diameter, using a 10x objective. Similarly, a 40x objective was used to measure the epithelium height of ductus epididymis, from its bottom to the apical edge.

\section{Results}

The environmental features of the sampling periods were recorded according to Table 1. 
TABLE 1: Mean and standard deviation values regarding temperature, humidity, and rainfall in the town of Sao Bento, Maranhao, Brazil, according to the period.

\begin{tabular}{lccc}
\hline \multicolumn{1}{c}{ Period of the year } & Temperature $\left({ }^{\circ} \mathbf{C}\right)$ & Humidity $(\%)$ & Rainfall $(\mathbf{m m})$ \\
\hline December 2010 & $27.52 \pm 1.23 \mathrm{a}$ & $75.97 \pm 8.30 \mathrm{a}$ & $6.57 \pm 16.58 \mathrm{a}$ \\
March 2011 & $26.32 \pm 0.70 \mathrm{~b}$ & $85.93 \pm 4.39 \mathrm{~b}$ & $2.37 \pm 4.31 \mathrm{~b}$ \\
June 2011 & $26.51 \pm 0.62 \mathrm{~b}$ & $80.55 \pm 3.36 \mathrm{c}$ & $0.79 \pm 2.47 \mathrm{~b}$ \\
September 2011 & $27.58 \pm 0.49 \mathrm{a}$ & $71.70 \pm 3.05 \mathrm{a}$ & $0.01 \pm 0.07 \mathrm{~b}$ \\
\hline
\end{tabular}

Means with different letters in the same row indicate a statistical significant difference $(\mathrm{p}<0.05)$ for the Student-Newman-Keuls $(\mathrm{SNK})$ test and the Cramer-von Mises normality test W-Sq 0.03979, $\mathrm{Pr}>\mathrm{W}-\mathrm{Sq}>0.2500$.

In all animals analyzed, the epididymis had the same general microscopy morphology, being divided into rete testis, with tortuous disposal, ductuli efferentes, and ductus epididymis (Figure 1A). The rete testis is twisted and it seems to be randomly anastomosed and lined with flattened squamous or low cuboidal epithelium, whereas the ductuli efferentes is a canalicular complex immersed in connective tissue, lined with simple cuboidal epithelium. The ductus epididymis, in turn, is covered by dense connective tissue and surrounded by loose connective tissue, and spermatozoids are observed in the lumen, with cellular debris.

The ductus epididymis is covered by loose and dense connective tissues (Figure 1B). Its epithelium is composed by elongated principal cells and flattened basal cells in contact to the basement membrane in greater numbers (Figure 1C), varying between pseudostratified columnar epithelium to simple cubic epithelium (Figure 1D). The stereo cilia are found in large amounts to allow the sperm move to the ductus deferens. Spermatozoids were found within all periods, in a lesser amount during the dry season.

In scanning electron microscopy, using the epididimal cryofracture technique, the disposal of pseudostratified stereo ciliated epithelium with sperm was observed in the lumen and on the edge of the tubule, with presence of secretion canaliculi. Epididymal epithelial cells are indicated by their structure, in a hexagonal shape, which allow greater flexibility for sperm transport (Figures 2A to 2C).
The region where the animals were collected has a humid tropical climate, with little variation in annual temperature; rainfall is observed in the first months of the year and humidity is constant throughout the year.

The ductus epididymis of the scorpion mud turtle in the rainy season consists of stereo ciliated pseudostratified cylindrical epithelium with main and basal cells and sperm in the duct (Figures 3A and 3C). In the dry season, the epithelium consists of simple cuboidal cells (Figures 3B and 3D), when the scorpion mud turtle presents an epididymis of irregular aspect, besides sperm degeneration. However, the presence of sperm was evidenced in both seasons.

The transmission electron microscopy image shows epithelial cells with juxtaposed cytoplasmic content, organelles, and the presence of sperm in the lumen, demonstrating that the organ presents a reproductive activity. In the rainy season, there're epithelial cells, with organelles and the presence of sperm (Figures 4A and 4B), whereas in the dry season there's an increase in the number of organelles (mitochondria) and disorganized epithelium with sperm (Figures 4C and 4D).

The morphometry regarding mean values of tubular and luminal diameters and epididymal epithelium height in the rainy season presented the highest mean values with significant differences indicating a reproductive activity. In the rainy season, one observed that, in the last sampling, the mean values of the tubular and luminal diameters increased, indicating epithelial variation (Table 2). 
FIGURE 1: Histological section of the scorpion mud turtle (Kinosternon scorpioides) epididymis. A: Divisions of the epididymis into rete testis (Rt), ductuli efferentes (Efd), and ductus epididymis (Ed). Scale bar: $200 \mu \mathrm{m}$. B: Ductus epididymis surrounded by dense connective tissue (Dct) and loose connective tissue (Lct); spermatozoids (Spz) in the lumen. Scale bar: $200 \mu \mathrm{m}$. C: stereo ciliated pseudostratified columnar epithelium (arrow) with principal cells (P), basal cells (B) and spermatozoids in the tubular lumen (Spz). Scale bar: $200 \mu \mathrm{m}$. D: Stereo ciliated pseudostratified columnar epithelium (arrow) and cubic simple epithelium (Cse), with spermatozoids (Spz) in the lumen. Scale bar: $200 \mu \mathrm{m}$ (HE).

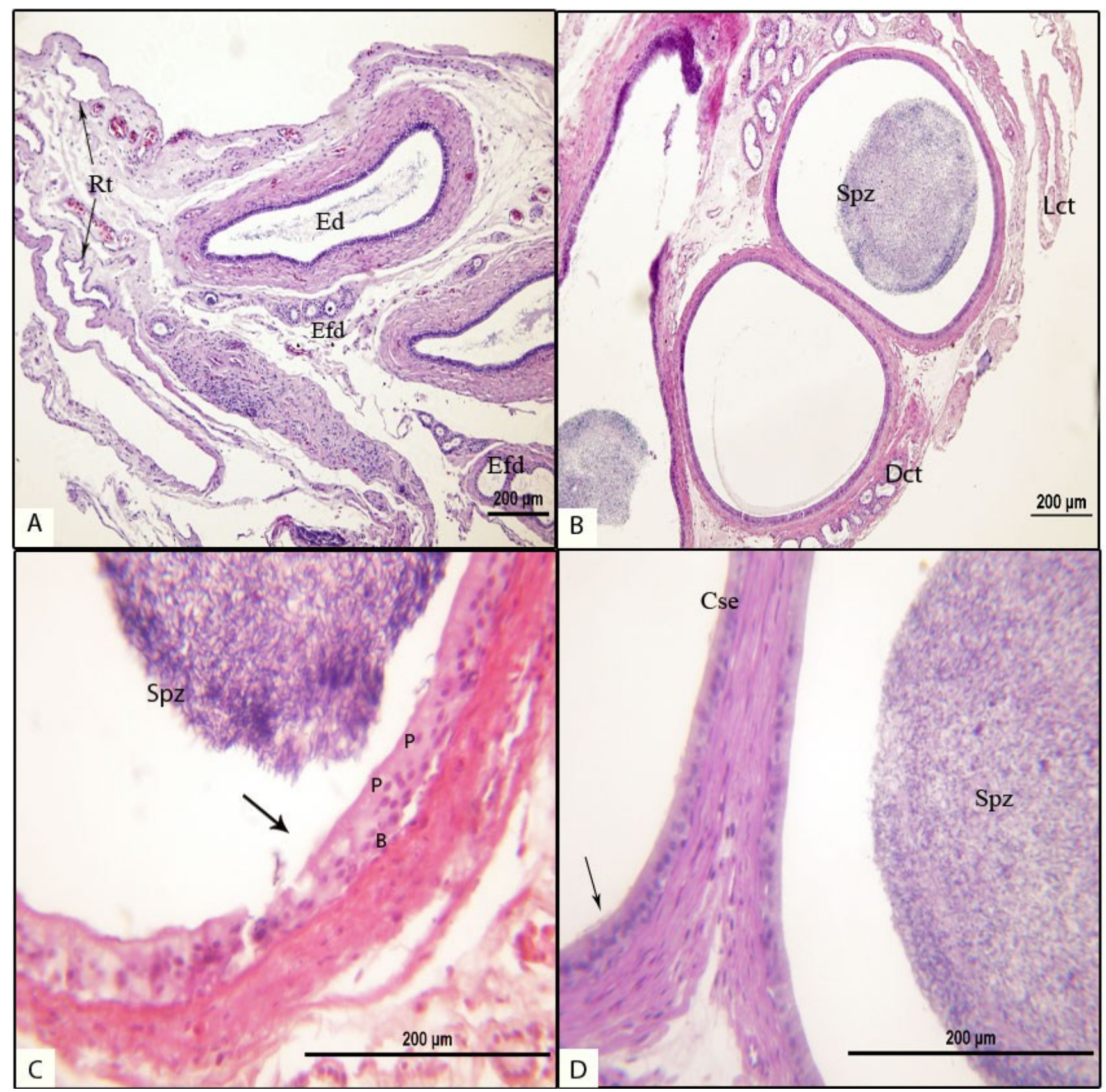


FIGURE 2: Photomicrography of scanning electron microscopy (SEM) of cryofractured scorpion mud turtle epididymis. A: epididymal duct with dense connective tissue (Dct) and loose connective tissue (Lct). Scale bar: $100 \mu \mathrm{m}$. B: Arrangement of stereo ciliated pseudostratified epithelium (arrow) with spermatozoids (Spz). Scale bar: $100 \mu \mathrm{m}$. C: Epididymis with the inner wall in hexagon shape (highlight) and secretory canaliculi (arrows), with stereo cilia (arrow head). Scale bar: $30 \mu \mathrm{m}$.

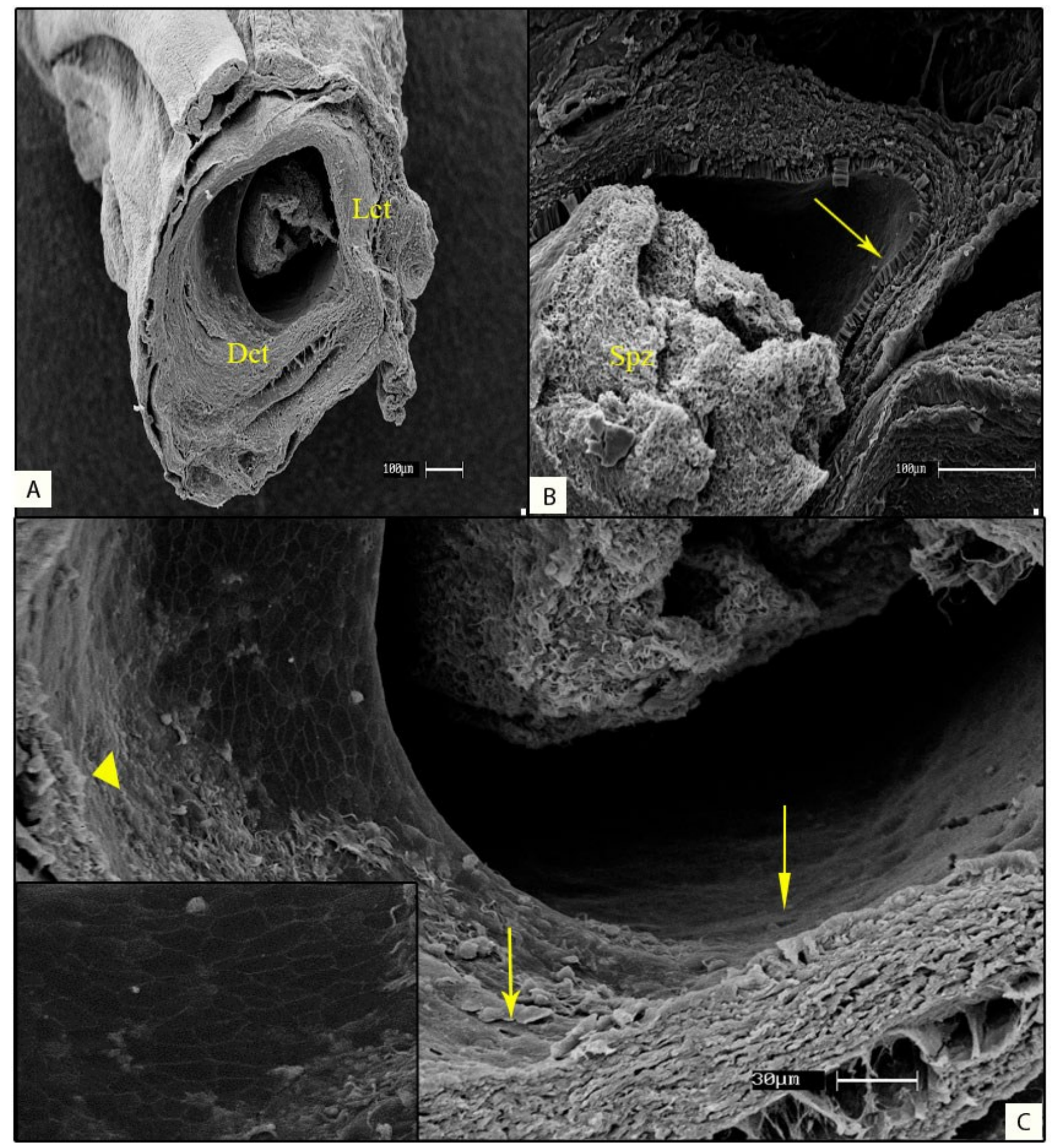


FIGURE 3: Histology of the epididymal duct of the scorpion mud turtle (Kinosternon scorpioides) in rainy and dry seasons. A and C: Epididymal duct in the rainy season with the presence of spermatozoids (Spz) in the lumen, and pseudostratified cylindrical epithelium with stereo cilia (Cpe). Scale bar: $200 \mu \mathrm{m}$. B and D: Epididymal duct in dry season, with spermatozoids (Spz), columnar cubic simple epithelium (Cse). Scale bar: $200 \mu \mathrm{m}(\mathrm{HE})$.

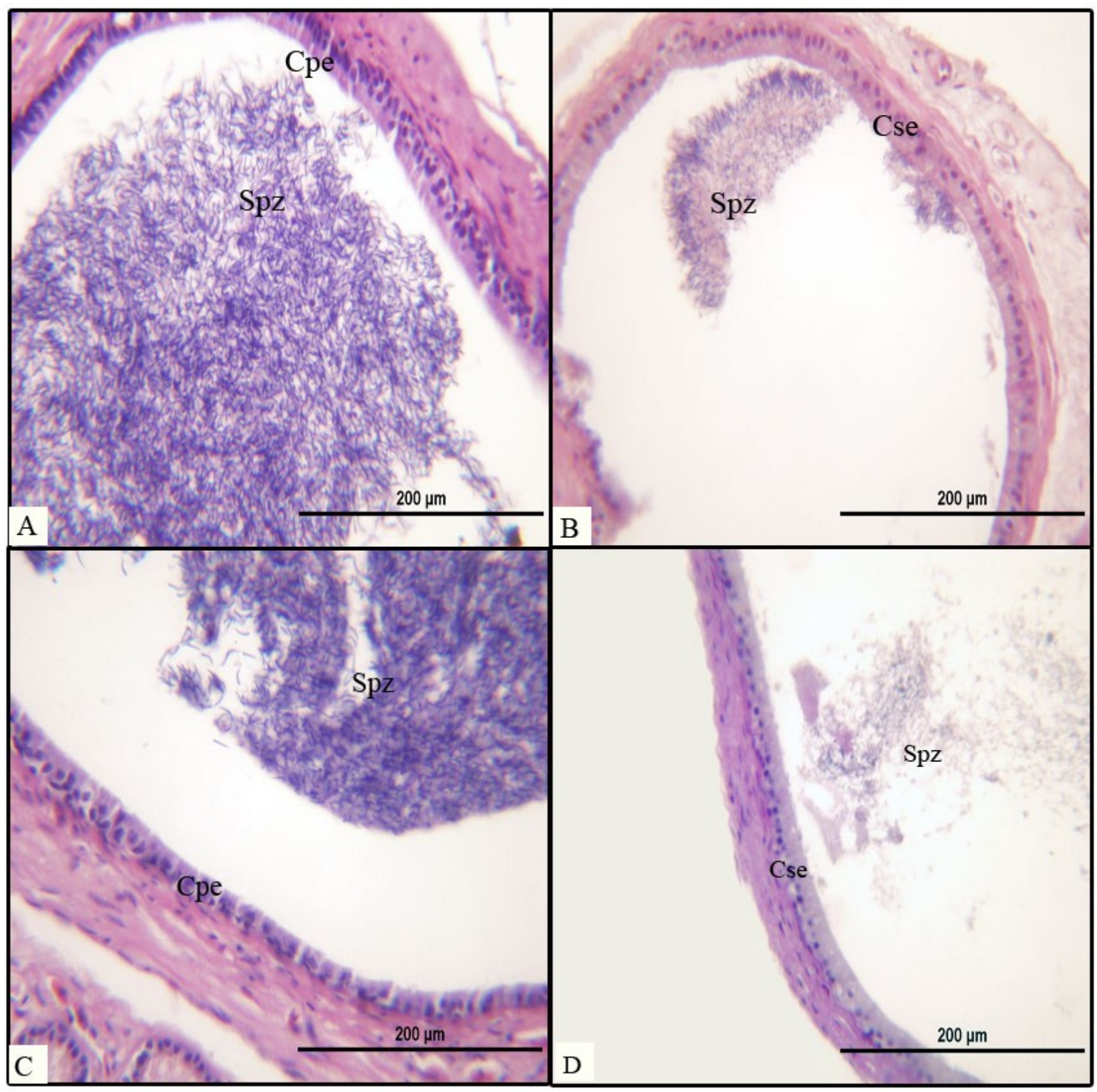


FIGURE 4: Fotomicrography of transmission electron microscopy of the epididymis in the scorpion mud turtle (Kinosternon scorpioides) in rainy and dry seasons. A and B: epididymis in the rainy season with cellular organization and cytoplasmatic organelles (mitochondria - arrow) and nucleus $(\mathrm{N})$, presence of stereo cilia (arrowhead) and spermatozoids (Spz). Scale bar: $2 \mu \mathrm{m}, 5$ $\mu \mathrm{m}$. C and D: epididymis in the dry season with epithelial disorganization and cytoplasmic organelles (mitochondria in large quantities) and spermatozoids. Scale bar: $5 \mu \mathrm{m}, 2 \mu \mathrm{m}$.

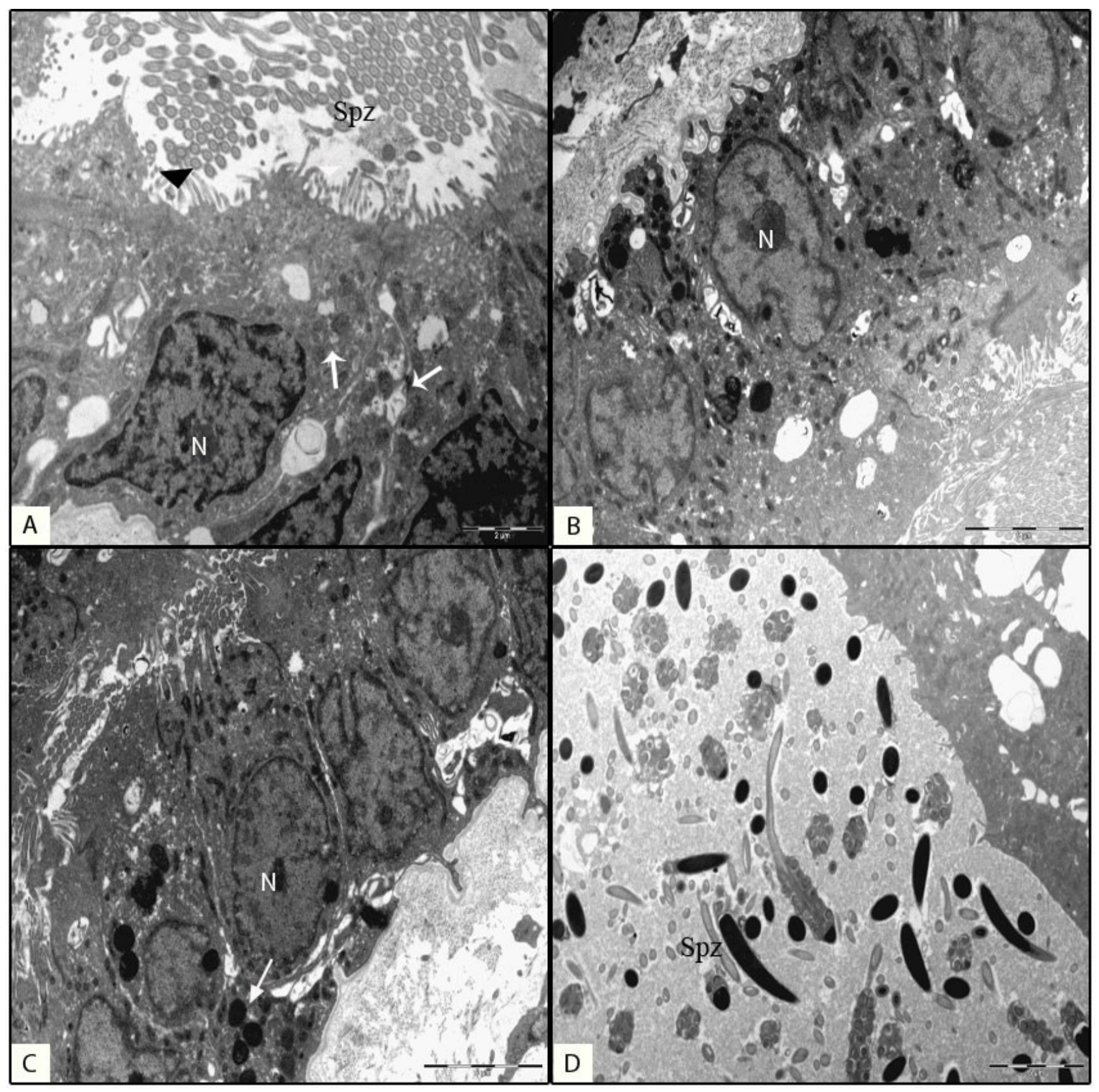


TABLE 2: Mean and standard deviation morphometry $(\mu \mathrm{m})$ of tubular and luminal diameters, and epithelial height of the epididymal ducts of the scorpion mud turtles (Kinosternon scorpioides) captured in Sao Bento, Maranhao, Brazil.

\begin{tabular}{|c|c|c|c|c|}
\hline \multirow{3}{*}{ Epididymal duct } & \multicolumn{4}{|c|}{ Period of the year } \\
\hline & \multicolumn{2}{|c|}{ Rainy season } & \multicolumn{2}{|c|}{ Dry season } \\
\hline & March 2011 & June 2011 & September 2011 & December 2010 \\
\hline Tubular diameter & $392.41 \pm 51.75 \mathrm{a}$ & $476.54 \pm 54.81 \mathrm{~b}$ & $295.82 \pm 56.42 \mathrm{c}$ & $370.52 \pm 51.59 \mathrm{a}$ \\
\hline Luminal diameter & $386.85 \pm 45.57 \mathrm{a}$ & $452.07 \pm 59.02 \mathrm{~b}$ & $268.46 \pm 53.77 \mathrm{c}$ & $345.85 \pm 54.41 \mathrm{a}$ \\
\hline Ephitelial height & $29.58 \pm 12.52 \mathrm{a}$ & $25.38 \pm 7.74 \mathrm{ab}$ & $27.81 \pm 8.32 \mathrm{abc}$ & $15.53 \pm 4.61 \mathrm{a}$ \\
\hline
\end{tabular}

Means with different letters in the same row indicate a statistical significant difference $(\mathrm{p}<0.05)$ for the Student-Newman-Keuls $(\mathrm{SNK})$ test and the Cramer-von Mises normality test W-Sq 0.03979, $\mathrm{Pr}>\mathrm{W}-\mathrm{Sq}>0.2500$.

\section{Discussion}

According to Lake (1957) and King et. al. (1995), in studies on birds, the epididymis presents an elongated and fusiform single structure, inserted in the testicles of the dorsomedial surface and the epididymis of pigeon was histologically described by Stefanini and Orsi (2005) divided into rete testis, ductuli efferentes, and epididymal duct. These characteristics are similar to those observed in the scorpion mud turtle.

There was a significant difference between the seasons; the diameters were higher in the rainy season, probably due to the amount of spermatozoids presents in the epididymis. These characteristics for this region of the state of Maranhao were equal to those observed by Pereira et al. (2007), corroborated by Chaves (2011).

Xiangkun et al. (2008) studied the turtles Trionyx sinensis and found out that on summer, i.e. the breeding period, one could observe a large number of principal cells in the epididymis, besides glycogen granules with lipids in the cytoplasm. Chaves (2011), with captive scorpion mud turtles, observed secretion of positive glycogen granules in epithelial cells and a mass of sperm in the epididymal ducts, which coincides with the freeliving scorpion mud turtles in the breeding period, being the energy production released by the cells.

The epididymal duct showed small annual variation with a significant increase in tubular caliber, intraluminal sperm storage, and the occurrence of mitochondria, lysosomes, endoplasmic reticulum, and variable vesicles in the cytoplasm of principal cells. These ultrastructural characteristics of the principal cells seem to indicate the occurrence of active endocytosis processes and degenerative characteristics were observed at the supranuclear cytoplasm level of the epididymal P cells on fall (ORSI et al., 2007).

McPherson and Marion (1981) studied a species of Alabama turtles (Sternotherus odoratus) and noticed that the epididymis is lightweight between July and September, i.e. within the same period in which the testicles are heavy, thus, one may say that there's a sperm move. It's also observed in the scorpion mud turtle, through morphometry, that when the testicles are plenty of sperm, the epididymis presents a lower density. However, as observed by McPherson and Marion (1981), the epididymides are plenty of sperm throughout the year, and in the scorpion mud turtle there're spermatozoids throughout the year in varying amounts between periods, but one couldn't make statements on their viability. Therefore, the scorpion mud turtle presents a reproductive sazonality characterized by the epididymal morphology.

\section{Acknowledgments}

The author thank to the State University of Maranhao (UEMA), the National Program of Academic Cooperation (Procad I - Amazon), the Foundation for Research Support of the State of Maranhao (FAPEMA), for financing this research, and the Brazilian Institute of Environment and Natural Resources (IBAMA), for support. 


\section{References}

CARVALHO, R. C.; SOUSA, A. L.; SILVA, A. L. A.; PEREIRA, J. G. Anatomia dos órgãos genitais do muçuã Kinosternon scorpioides macho (Chelonia, Kinosternidae). Pesquisa Veterinária Brasileira, Seropédica, v. 30, n. 4, p. 289-294, 2010.

CHAVES, L. P. F. A. Orgãos genitais masculino e nível sérico de testosterona de jurará (Kinosternon scorpioides, Linnaeus, 1766) criado em cativeiro na região da baixada maranhense no estado do maranhão. 2011. 92 f. Dissertação (Mestrado em Ciências Animal) - Universidade Estadual do Maranhão, São Luís. 2011.

ERNST, C. H.; BARBOUR, R. W. Turtles of the United States. Lexington: University of Kentucky Press, 1989. 347 p.

KING, A. S. Aparelho urogenital das aves. In: GETTY, R. (Ed.). Anatomia dos animais domésticos. 5. ed. Rio de Janeiro: Guanabara Koogan, 1995. p. 1798-1805.

LAKE, P. E. The male reproductive tract of the fowl. Journal of Anatomy, Maiden, v. 91, p. 116-129, 1957.

MCPHERSON, R. J.; MARION, K. R. Seasonal testicular cycle of the stinkpot turtle (Sternotherus odoratus) in Central Alabama. Herpetologica, Lawrence, v. 37, n. 1, p. 33-40, 1981.

ORSI, A. M.; DOMENICONI, F. R.; SIMÕES, K.; STEFANINI, A. M.; BARALDI-ARTONI, M. S. Variabilidade sazonal no ducto epididimário de codorna doméstica: observações morfológicas. Pesquisa Veterinária Brasileira, Seropédica, v. 27, n. 12, p. 495500, 2007.

PEREIRA, L. A. Aspectos da biologia, ecologia e extrativismo de Kinosternon scorpioides Linnaeus, 1766 (Reptila, Chelonia, Kinosternidae) no Município de São Bento - Baixada Maranhense (Maranhão, Brasil). 2004. 107 f. Dissertação (Mestrado em Agroecologia) - Universidade Estadual do Maranhão, São Luís. 2004.
PEREIRA, L. A.; SOUSA, A. L.; CUTRIM, M. V. J.; MOREIRA, E. G. Características ecológicas do habitat de Kinosternon scorpioides scorpioides Linnaeus, 1766 (Reptila, Chelonia, Kinosternidae) no Município De São Bento - Baixada Maranhense (Maranhão, Brasil). Boletim do Laboratório de Hidrobiologia, São Luís, v. 20, p. 9-14, 2007.

PRITCHARD, P. C.; TREBBAU, P. The turtles of Venezuela. Ithaca: Society the Study of Amphibians and Reptiles, 1984. 403 p.

ROCHA, M. B.; MOLINA, F. B. Algumas observações sobre a biologia e manejo do muçuã. Aquacultura, São Paulo, n. 2, p. 25 26, 1987.

SBH. Brazilian reptiles - List of species. 2005. Disponível em: $<$ http://www.sbherpetologia.org.br $>$. Sociedade Brasileira de Herpetologia. Acesso em: 5 jan. 2012.

SCHUMACHER, J. Reptiles and amphibians. In: THURMON, J. C.; TRAQUILLI, W. J.; BENSON, G. L. (Ed.). Lumb \& Jones veterinary anesthesia. 3. ed. Baltimark: Willians \& Wilkins, 1996. p. 671-685.

STEFANINI, M. A.; ORSI, A. M. Características morfométricas da região epididimária do pombo doméstico (Columba Lívia, L.). Brazilian Journal of Veterinary and Animal Science, São Paulo, v. 36, n. 2, s/paginação, 2005.

VANZOLINI, P. E.; RAMOS-COSTA, A. M. M.; VITT, L. J. Répteis da Caatinga. Rio de Janeiro: Academia Brasileira de Ciências, 1980. 161 p.

XIANGKUN, H.; LI, Z.; MEIYING, L.; HUIJUN, B.; NAINAN, H. QIUSHENG, C. Seasonal changes of sperm storage and correlative structures in male and female soft-shelled turtles, Trionyx sinensis. Animal Reproduction Science, Amsterdam, v. 108, p. 3-4, 2008. 